\title{
Serum Resistin Level in Obese Male Children
}

\author{
Anis Amirhakimi, Hamdollah Karamifar, Hosein Moravej, \\ and Gholamhosein Amirhakimi
}

Department of Pediatrics, Namazee Hospital, Shiraz University of Medical Sciences, Shiraz, Iran

Correspondence should be addressed to Anis Amirhakimi, happylife12@yahoo.com

Received 26 October 2010; Accepted 26 January 2011

Academic Editor: Gianluca Iacobellis

Copyright () 2011 Anis Amirhakimi et al. This is an open access article distributed under the Creative Commons Attribution License, which permits unrestricted use, distribution, and reproduction in any medium, provided the original work is properly cited.

Objectives. Resistin is a member of cysteine-rich molecules. Several studies have been carried out to determine the biological effect of resistin, nevertheless a significant number are animal studies. All the studies performed regarding the relationship between serum resistin and obesity were merely accomplished in women. To the best of our knowledge, there is no survey on the correlation of the serum resistin level and obesity in male children. The aim of the present study is to assess serum concentration of resistin in obese male children. Methods. Between June 2009 and January 2010, we enrolled 42 randomly selected obese male students (body mass index $(\mathrm{BMI})>95$ th percentile, age $15.7 \pm 1.5)$. Thirty-eight healthy age-matched male students with normal BMI $(<85$ th percentile) were selected as a control group for the purpose of comparison of the serum resistin levels. Results. Serum resistin levels were measured in obese and control group. No significant difference was found between resistin levels of the 2 groups (obese: $9.21 \pm 5.6 \mathrm{ng} / \mathrm{mL}$ versus normal: $9.83 \pm 4.3 \mathrm{ng} / \mathrm{mL} ; P=.582$ ). There was no significant correlation between serum resistin level and BMI. Assessing the resistin level in male subjects was the distinct feature of our study. The outstanding finding of this research is that there is no correlation between serum resistin level and obesity. Conclusion. We have demonstrated that there is no correlation between obesity in male children and resistin level. Consequently, metabolic abnormalities of insulin resistance seen in obese male patients are not related to resistin.

\section{Introduction}

Adipose tissue, involved in control of metabolism, is an active endocrine organ that secrets a number of hormones and cytokines termed adipocytokines [1-3]. These include leptin, interleukin-6, tumor necrosis factor- $\alpha$, adiponectin, and resistin [2-10]. Adipocytokines have different effects and act through autocrine, paracrine, and endocrine pathways [11-14]. Having been recently identified as a novel adipocytokines, resistin is a members of cysteine-rich molecules [1]. Several studies have been carried out to determine the biological effect of resistin; nevertheless, a significant number of them have been animal studies. Recently, animal studies have shown that the serum resistin level remarkably rises in obese mice and that it may be a harbinger for insulin resistance and diabetes. Despite the fact that widespread research has been conducted to figure out the relationship between serum resistin and obesity, this issue still remains debated. One recent study evaluated serum resistin level in polycystic ovary syndrome, a metabolic disease linked with insulin resistance and obesity in women [15]. To the best of our knowledge, there are very limited surveys on the correlation of serum resistin level and obesity in children. The aim of the present study was to assess serum concentration of resistin in obese male children.

\section{Materials and Methods}

2.1. Study Population. Between June 2009 and January 2010, we enrolled 42 randomly selected obese male students (body mass index $(\mathrm{BMI})>95$ th percentile, age $15.7 \pm 1.5$ ). Thirtyeight healthy age-matched male students with normal BMI $(<85$ th percentile) were selected as a control group for the purpose of comparison of the serum resistin levels. Clinical history with thorough physical examination was performed in all subjects. Written informed consent was obtained from all students' parents before participation in the study. 
Subjects with the following characteristics were excluded from the study: (1) any pathological or suspicious clinical abnormality in history or physical examination (other than simple obesity), (2) short stature (height for age <10th percentile), (3) acute illness, and (4) abnormal laboratory data. The study protocol was approved by the local ethics committee.

2.2. Measurement of Serum Resistin. Blood samples were obtained and stored at $-70^{\circ} \mathrm{C}$ until analysis. Serum resistin concentration was measured using a Human Resistin ELISA kit (EIA-4572, DRG instruments GmbH, Germany) in the Endocrinology and Metabolism Research Laboratory.

2.3. Statistical Analysis. All values are presented as mean \pm $\mathrm{SD}$. Comparisons between groups were made using Student's $t$-test. For all analyses, $P$-value $<.05$ was considered as statistically significant.

\section{Results}

3.1. Subjects Characteristics. Forty-two obese male students were randomly selected (age: $15.7 \pm 1.5$ yrs; BMI: $30.1 \pm$ $4.3 \mathrm{~kg} / \mathrm{m}^{2}$ ). Thirty-eight healthy age-matched male students with normal BMI (BMI: $18.7 \pm 2.5 \mathrm{~kg} / \mathrm{m}^{2}$ ) were selected as a control group. There was a statistically significant difference between BMI of obese subjects and normal students as expected $(P=.001)$.

3.2. Serum Resistin Measurements. Serum resistin levels were measured in obese and control groups. No statistically significant difference was found between resistin levels of the 2 groups (obese: $9.21 \pm 5.6 \mathrm{ng} / \mathrm{mL}$ versus control group: 9.83 $\pm 4.3 \mathrm{ng} / \mathrm{mL} ; P=.582)$. There was no significant correlation between serum resistin level and BMI.

\section{Discussion}

Secreted by adipocytes, adipocytokines are proteins that play an important role in the regulation of energy $[1,5,9]$. Adipocytokines include leptin, adiponectin, and resistin [210]. Leptin is a hormone that reduces the appetite and enhances metabolism [16-18]. It appears that obese people produce more leptin because of increase in the number of fat cells [16-18]. Obesity is associated with insulin resistance, and leptin level is significantly correlated with insulin resistance $[16,17]$. Adiponectin, a novel peptide present specifically in adipose tissue, has been appreciated to have inverse correlation with insulin resistance [19]. Resistin was originally recognized as a factor correlating obesity and diabetes by impairing insulin sensitivity in mice [1]. Preliminary animal studies put forward that obesity is associated with increased circulatory resistin concentrations [1]. Later studies, nonetheless, have determined opposite results, describing that resistin production goes down in obese rodents and is suppressed by free fatty acids. All the studies performed regarding the relationship between serum resistin and obesity were merely accomplished in women.
Assessing the resistin level in male subjects was the distinct feature of the present study. The outstanding finding of this research is that no correlation between serum resistin level and obesity was found.

Studies of resistin showed that resistin gene expression in 3T3-L1 adipocytes was inhibited by insulin and TNF- $\alpha$ which are increased in obesity [20]. Studies of resistin mRNA and protein expression in adipose tissue of humans have provided additional support that resistin may not play a role in obesity in humans. One report found that isolated human adipocytes have very low resistin mRNA levels [21].

\section{Conclusion}

In conclusion, it is demonstrated that there is no correlation between obesity in male children and resistin level. Consequently, metabolic abnormalities of insulin resistance seen in male obese patients are not related to resistin.

\section{References}

[1] Y. Liu, Q. Wang, Y. B. Pan, Z. J. Gao, Y. F. Liu, and S. H. Chen, "Effects of over-expressing resistin on glucose and lipid metabolism in mice," Journal of Zhejiang University: Science B, vol. 9, no. 1, pp. 44-50, 2008.

[2] H. Sinorita, R. H. Asdie, R. B. Pramono, L. B. Purnama, and A. H. Asdie, "Leptin, adiponectin and resistin concentration in obesity class I and II at Sardjito Hospital Yogyakarta," Acta Medica Indonesiana, vol. 42, no. 2, pp. 74-77, 2010.

[3] Z. T. Bloomgarden, "Adiposity and diabetes," Diabetes care, vol. 25, no. 12, pp. 2342-2349, 2002.

[4] C. M. Kusminski, P. G. McTernan, and S. Kumar, "Role of resistin in obesity, insulin resistance and Type II diabetes," Clinical Science, vol. 109, no. 3, pp. 243-256, 2005.

[5] R. Baratta, S. Amato, C. Degano et al., "Adiponectin relationship with lipid metabolism is independent of body fat mass: evidence from both cross-sectional and intervention studies," Journal of Clinical Endocrinology and Metabolism, vol. 89, no. 6, pp. 2665-2671, 2004.

[6] J. Vendrell, M. Broch, N. Vilarrasa et al., "Resistin, adiponectin, ghrelin, leptin, and proinflammatory cytokines: relationships in obesity," Obesity Research, vol. 12, no. 6, pp. 962-971, 2004.

[7] O. Ukkola, "Resistin—a mediator of obesity-associated insulin resistance or an innocent bystander?" European Journal of Endocrinology, vol. 147, no. 5, pp. 571-574, 2002.

[8] C. L. McTernan, P. G. McTernan, A. L. Harte, P. L. Levick, A. H. Barnett, and S. Kumar, "Resistin, central obesity, and type 2 diabetes," Lancet, vol. 359, no. 9300, pp. 46-47, 2002.

[9] A. R. Shuldiner, R. Yang, and DA. W. Gong, "Resistin, obesity, and insulin resistance-the emerging role of the adipocyte as an endocrine organ," New England Journal of Medicine, vol. 345, no. 18, pp. 1345-1346, 2001.

[10] P. A. Kern, G. B. Di Gregorio, T. Lu, N. Rassouli, and G. Ranganathan, "Adiponectin expression from human adipose tissue: relation to obesity, insulin resistance, and tumor necrosis factor- $\alpha$ expression," Diabetes, vol. 52, no. 7, pp. 1779-1785, 2003.

[11] Y. H. Yu and H. N. Ginsberg, "Adipocyte signaling and lipid homeostasis: sequelae of insulin-resistant adipose tissue," Circulation Research, vol. 96, no. 10, pp. 1042-1052, 2005. 
[12] K. F. Petersen and G. I. Shulman, "Etiology of insulin resistance," American Journal of Medicine, vol. 119, no. 5, pp. S10-S16, 2006.

[13] C. M. Rondinone, "Adipocyte-derived hormones, cytokines, and mediators," Endocrine, vol. 29, no. 1, pp. 81-90, 2006.

[14] T. Ronti, G. Lupattelli, and E. Mannarino, "The endocrine function of adipose tissue: an update," Clinical Endocrinology, vol. 64, no. 4, pp. 355-365, 2006.

[15] K. C. Lewandowski, K. Szosland, C. O’Callaghan, B. K. Tan, H. S. Randeva, and A. Lewinski, "Adiponectin and resistin serum levels in women with polycystic ovary syndrome during oral glucose tolerance test: a significant reciprocal correlation between adiponectin and resistin independent of insulin resistance indices," Molecular Genetics and Metabolism, vol. 85, no. 1, pp. 61-69, 2005.

[16] T. Yamauchi, J. Kamon, H. Waki et al., "The fat-derived hormone adiponectin reverses insulin resistance associated with both lipoatrophy and obesity," Nature Medicine, vol. 7, no. 8, pp. 941-946, 2001.

[17] B. B. Kahn and J. S. Flier, "Obesity and insulin resistance," Journal of Clinical Investigation, vol. 106, no. 4, pp. 473-481, 2000.

[18] J. M. Friedman, "The function of leptin in nutrition, weight, and physiology," Nutrition Reviews, vol. 60, no. 10, pp. S1-S14, 2002.

[19] G. Gonullu, H. Kahraman, A. Bedir, A. Bektas, and I. Yücel, "Association between adiponectin, resistin, insulin resistance, and colorectal tumors," International Journal of Colorectal Disease, vol. 25, no. 2, pp. 205-212, 2010.

[20] N. Shojima, H. Sakoda, T. Ogihara et al., "Humoral regulation of resistin expression in 3T3-L1 and mouse adipose cells," Diabetes, vol. 51, no. 6, pp. 1737-1744, 2002.

[21] D. B. Savage, C. P. Sewter, E. S. Klenk et al., “. Resistin/FIZZ3 expression in relation to obesity and peroxisome proliferatoractivated receptor- $\gamma$ action in humans," Diabetes, vol. 50, no. 10, pp. 2199-2202, 2001. 


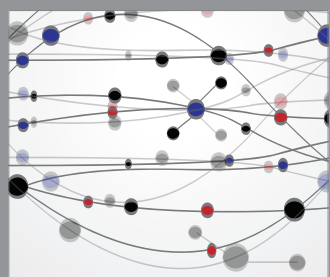

The Scientific World Journal
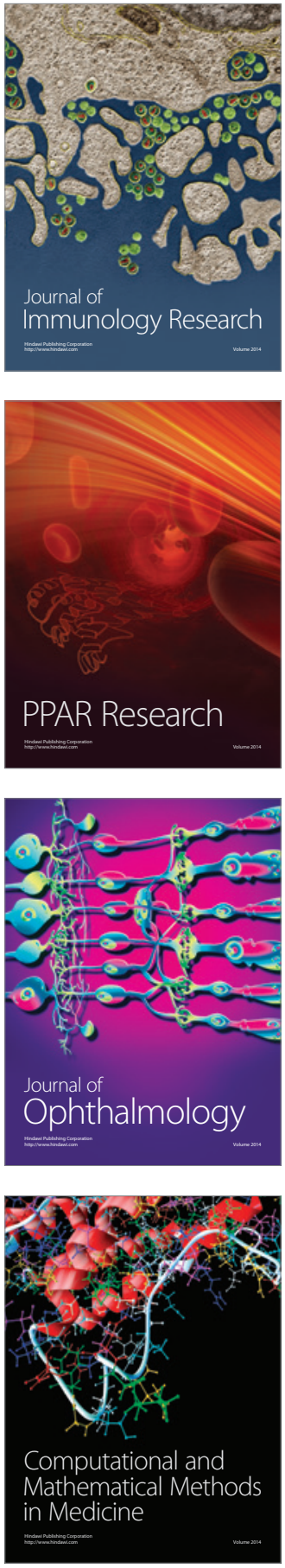

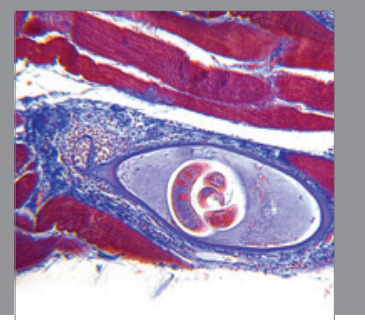

Gastroenterology

Research and Practice
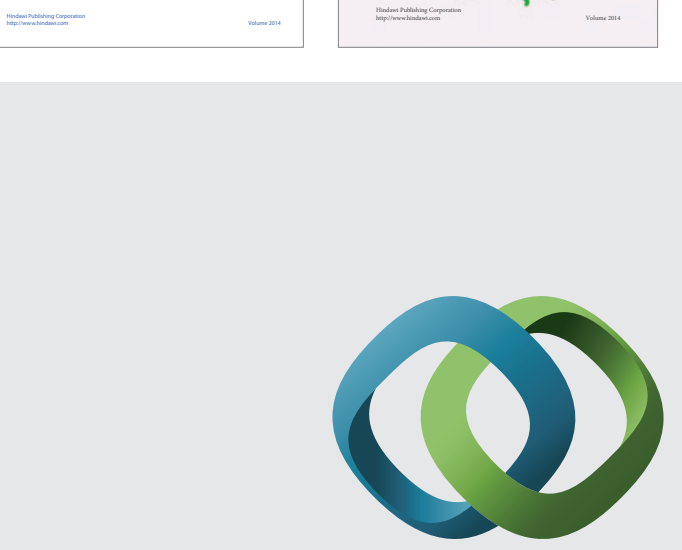

\section{Hindawi}

Submit your manuscripts at

http://www.hindawi.com
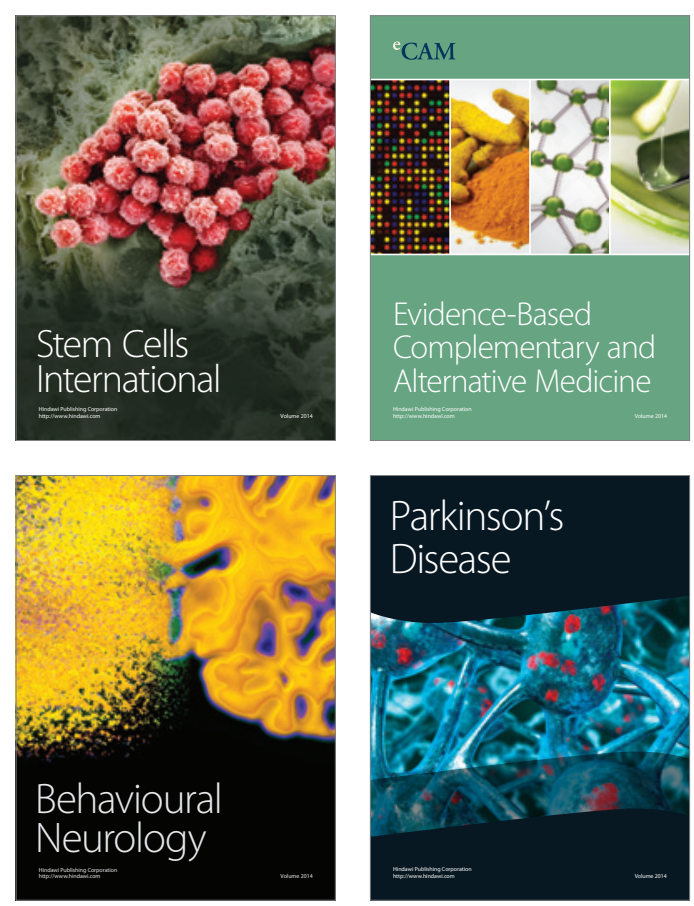

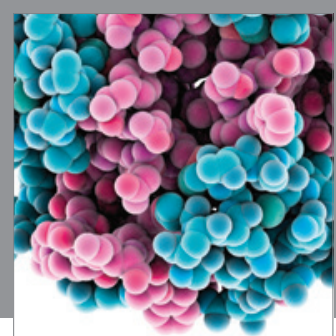

Journal of
Diabetes Research

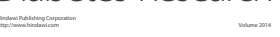

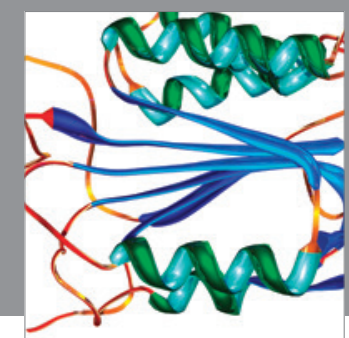

Disease Markers
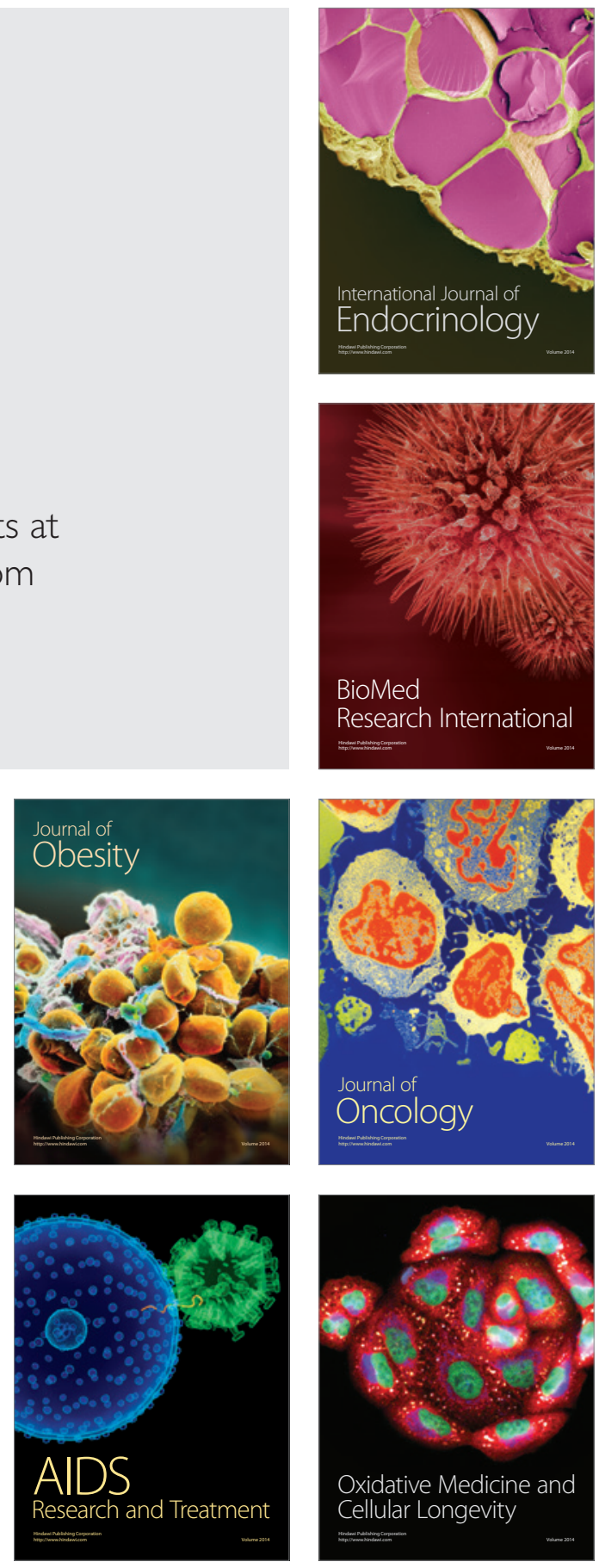